DOI: https://doi.org/10.34069/AI/2021.43.07.5

How to Cite:

Popelo, O., Garafonova, O., Tulchynska, S., Derhaliuk, M., \& Berezovskyi, D. (2021). Functions of public management of the regional development in the conditions of digital transformation of economy. Amazonia Investiga, 10(43), 49-58. https://doi.org/10.34069/AI/2021.43.07.5

\title{
Functions of public management of the regional development in the conditions of digital transformation of economy
}

\section{Функції державного управління регіональним розвитком в умовах цифрової трансформації економіки}

Received: June 20, 2021

\begin{abstract}
In this study, a methodological approach based on the model of the differential equations system to determine the impact of the functions of public administration of the regional development in the context of digital transformation is proposed. As digital transformation involves changes in management models of systems at different levels in order to improve their efficiency, this also applies to public management of the regional development. Based on the system approach, social, reproductive and mobilizing functions of state management of the regional development were singled out. To determine the impact of public administration functions on the regional development, it is proposed to use a model of differential equations. Different weights of the influence of the functions of state management of the regional development in the conditions of digital transformation are characterized by dynamic changes in the amplitude of
\end{abstract}

Accepted: August 2, 2021
Анотація

У дослідженні запропоновано методологічний підхід для визначення впливу функцій державного управління регіональним розвитком у контексті цифрової трансформації, заснований на моделі системи диференціальних рівнянь. Оскільки цифрова трансформація передбачає зміни в моделях управління системами на різних рівнях 3 метою підвищення їх ефективності, це стосується i державного управління регіональним розвитком. На основі системного підходу було виділено соціальні, репродуктивні та мобілізуючі функції державного управління регіональним розвитком. Для визначення впливу функцій державного управління на регіональний розвиток пропонується використовувати модель диференціальних рівнянь. Різні ваги впливу функцій державного управління регіональним розвитком в умовах цифрової трансформації

\footnotetext{
15 Dr. of Economics, Associate Professor, Associate Professor of the Department of Management and Civil Service, Chernihiv Polytechnic National University, Ukraine.

${ }^{16}$ Dr. of Economics, Professor, Professor of the Department of Management, Kyiv National Economic University named after Vadym Hetman, Ukraine.

${ }^{17}$ Dr. of Economics, Professor, Professor of the Department of Economics and Entrepreneurship, National Technical University of Ukraine "Igor Sikorsky Kyiv Polytechnic Institute", Kyiv, Ukraine.

${ }^{18} \mathrm{PhD}$ in Economics, Senior Lecturer of the Department of Economics and Entrepreneurship, National Technical University of Ukraine "Igor Sikorsky Kyiv Polytechnic Institute", Kyiv, Ukraine.

${ }^{19} \mathrm{PhD}$ in Public Administration, Professor of the Department of Management and Public Administration, IHE “Academician Yuriy Bugay International Scientific and Technical University”, Kyiv, Ukraine.
} 
fluctuations of integral indices of the modules of the functionalities of social, reproductive and mobilization functions. Scientific novelty of this study is the development of a methodological approach based on the model of the differential equations system to determine social, reproductive and mobilizing functions of public administration of the regional development in the context of digital transformation.

Keywords: public management, regional development, digitalization, information economy, administration.

\section{Introduction}

Today, in the current conditions of the world economy, increasing threats to economic security of national economies, challenges to businesses as a result of the COVID-19 pandemic, digital transformation of the functioning of economic systems of various levels is becoming increasingly important. Digital transformation involves changes in management models of systems at different levels in order to increase the efficiency of their activities. In the context of digital transformation, it is impossible to ignore such a problem as public administration of the regional development. Digital transformation makes it possible both to improve existing management methods, and to stimulate the emergence of new creative, evolutionarily progressive, innovative management methods. In turn, changes in public administration in the context of digital transformation provide an opportunity to modernize the development of regional economic systems and to achieve the goals of social, economic and environmental sustainable growth.

The aim of the article is to develop methodological bases for determining the impact of public administration functions of the regional development in the context of digital transformation. To achieve this goal, the authors have identified and solved the following tasks: the features of digital transformation are clarified; using the system approach, functions of state management of regional development are singled out; the direction of efforts of social, reproductive and mobilizing functions on the development of regional economic systems is outlined; the methodical approach for the definition of the influence of functions of state management of the regional development in the conditions of digital transformation based on the model of the differential equations system is динамічними змінами амплітуди коливань інтегральних показників модулів функціональних можливостей соціальної, репродуктивної та мобілізаційної функцій. Науковою новинкою даного дослідження $є$ розробка методологічного підходу на основі моделі системи диференціальних рівнянь для визначення соціальних, репродуктивних та мобілізуючих функцій державного управління регіональним розвитком в контексті цифрової трансформації.

Ключові слова: державне управління, регіональний розвиток, цифровізація, інформаційна економіка, адміністрування.

offered; the proposed methodological approach to the regions of Ukraine is tested.

\section{Theoretical Framework}

Many scientists have devoted a lot of research to the study of the mechanisms of public administration in various spheres of activity, features of management of the regional development and issues of digital economy, among which the following should be noted: Arefieva O., et al (2021), Becerra L., et al (2020); Bouckaert G. (2019); Castellanos J. (2019); De Leon C.A.G. (2019); Efremov A. (2020); Halkos G., et al (2021); Houston D., et al (2021); Khanin S., et al (2021), Krasniqi I. (2019); Kraynyuk L., et al (2020); Ljungholm D.P. (2017); Mukhametzhan S.O., et al (2020); Petit Jean M. \& and Brunet, S (2017); Salbaroli E. \& Mazzini, G (2018); Samiilenko H., et al (2021), Samoilovych A., et al (2021), Skica T. \& Dvouletý, O. (2018); Wu D. (2018); Xu Y. \& Li, A. (2019); Yin X. (2018) and others.

The author of the article Efremov A. based on the structural and functional analysis of existing legal mechanisms offers a model of the mechanism for identifying and eliminating systemic legal restrictions on the public administration digitalization (Efremov, 2020).

In the article (Arefieva et al, 2021), the authors investigate the economic security system in the conditions of the powers transformation. The article (Samiilenko et al, 2021) systematizes the information on the main transformational changes of modern clustering in the conditions of digitalization are formulated.

In the research (Samoilovych et al, 2021), the current state of the implementation of digital 


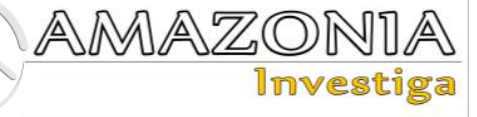

technologies in Ukraine and the world in the context of the information economy development is studied. Within the article (Khanin et al, 2021), the conditions and measures of the activation of intellectual-innovative determinants of the intensification of the development of regional economic systems are determined.

The authors of the article Mukhametzhan S., Junusbekova G. and Daueshov M. noted the main directions of economic growth of urban areas of Kazakhstan, i.e.: flexible management, proper control and management of urbanization, the use of best practices in developing urban strategies, policy development for different regions. Scientists recommend creating an integrated multi-level management system that provides feedback and preventive management, classifying consequences of the urban policy in the regions and consequences of achieving the goals of strategic development of the country (Mukhametzhan et al., 2020).

Based on the comprehensive analysis of the definition of coordinated development of the regional economy in the work of Chinese authors $\mathrm{Xu} \mathrm{Y.} \mathrm{and} \mathrm{Li} \mathrm{A.,} \mathrm{the} \mathrm{definition} \mathrm{of} \mathrm{the} \mathrm{scientific}$ subtext of the coordinated development of the regional economy is considered, and three indicators to assess the coordinated development of the regional economy are put forward $(\mathrm{Xu} \&$ Li, 2019).

A Spanish scholar Castellanos J. analyzes the application of social responsibility in the roundthe-clock management of public administrations, its inclusion in the guidelines governing its activities, and responsible actions that administrations are obliged to take in various spheres of life they affect, such as education, research, culture, sports, consumption of socially responsible products and services, inclusive policies, employment, environmental protection and development cooperation (Castellanos, 2019).

The results of a study by Czech scholars (Skica \& Dvouletý, 2018) have clear consequences for politicians, given the information on the regions with the largest / smallest size of public administration at the local level.

The study by Belgian researchers Petit J. and Brunet $S$. aims to analyze the relationship between expectations and public administration on the basis of a single study that focuses on a specific government body responsible for developing knowledge for policy making (Petit and Brunet, 2017).

The paper of the British research Houston D., Varna S. and Docherty I. focuses on the comparative analysis of economic and planning policy documents of Scotland, England and Great Britain and conclusions of expert seminars held in Scotland, which identify four key policy areas for "inclusive growth", namely: skills, transport and housing for young people; cityregional management; nurse; and accommodation. Among the factors contributing to the development of inclusive growth policies, the authors include necessary political forces; the unification of political discourse and public institutions; inclusive governance and participatory democracy (Houston et al., 2021).

\section{Methodology}

The separation of public administration functions and their impact on the development of regional economic systems is based on such methods of scientific knowledge as theoretical generalization, abstraction, induction and deduction, comparison, etc. These methods, as well as the application of a system approach, make it possible to identify the functions of public administration of the regional development in the context of digital transformation, as well as to determine their impact on regional economic systems. To identify the impact of public administration functions, the authors used a model of the differential equations system, which allows to obtain the values of functional, social, reproductive and mobilizing functions of public administration. The use of this methodological approach will help reduce the differentiation in the values of integrated indices of economic development of regional economic systems.

\section{Results and Discussion}

The role of public administration in the regional development should be considered under the prism of decentralization, which is typical for European countries. Ukraine does not stay away from these processes. As a result of the power decentralization, the role of regional government and local self-government is increasing.

Functions of public administration reflect a special form of the regional development process, taking into consideration the interaction of all economic entities in the context of digital transformation. Functions of public administration as a certain implementation of the 
process have a determining influence on the reproduction of economic, social and environmental potential of the region. In our opinion, the use of the systematic approach is important for the separation of functions of state management of the regional development, which makes it possible to single out purposeful activities of regional economic systems and to intensify their functioning taking into consideration objective laws of social development.

Functions of state regulation of the regional development in the context of digital transformation include social, reproductive and mobilization functions.

Regarding the social function, its main focus is to improve the quality and standard of living of the population, to reduce the asymmetry of social security between different regions and territories, as well as between urban and rural populations. The social function is the basis of socially oriented regional and state policy, ensures the reproduction of human and intellectual potential, helps to reduce disparities in social security of various segments of the population, sociohumanitarian development of regions and the country as a whole. As well, the social function is a tool for raising public ideals and comprehensive development of an individual, the formation of national dignity and the highest human values, promotes freedom, justice, equality in social and regional development. In the process of forming the social space of the regions there is a direction of individual behavior in society, the transfer of historical and cultural experience of generations, traditions, patriotism and more. This function is a stimulator of the regional development in the areas of:

- increasing indicators of demographic development;

- construction and improvement of the social protection system of the population of the regions;

- development of the social infrastructure and improving the quality of social services;

- increasing employment using the principle of inclusive regional development;

- ensuring non-inflationary growth of household incomes in accordance with European standards;

- implementation of regional and state social programs and projects;

- increasing control over the compliance with social standards of quality of life, taking into account requirements of direct end users of social services, considering regional characteristics and needs of the population;

- rationalization of the use of free time of the population of the regions, etc.

Returning to the functions of state regulation of the regional development in the context of digital transformation, the reproductive function is outlined. The reproductive function influences the process of expanded reproduction of regional economic systems in accordance with challenges of digital transformation of the regional development and the unique opportunities of the regions.

The reproductive function of public administration of the regional development provides:

- directing the production potential of the regional development to meet growing needs of the regions;

- the most careful use of available nonrenewable resources without harm to future generations;

- modernization of spatial economic systems in the conditions of digital transformation;

- increasing the intellectual potential of the regions;

- production of innovative products, both for domestic and foreign markets;

- increasing the competitiveness of production and economic systems;

- development of the innovation infrastructure.

The mobilization function is the third function of state management of the regional development singled out by the authors in the conditions of digital transformation. Its main focus is on the maximum mobilization of all resource capabilities of regional economic systems, their effective distribution and redistribution in order to increase the efficiency of expanded reproduction and improve living standards. The action of the mobilization function of public administration in the conditions of digital transformation is aimed at:

- achieving optimal proportions between the use, attraction, distribution and redistribution of resources of regional economic systems and the country as a whole;

- concentration of efforts and resources on innovative areas of production and highly efficient areas of production; 
- modernization of regional economic systems in the conditions of digital transformation;

- encouraging regional actors to use resources more efficiently and carefully;

- interaction and integration of subjects of regions of different forms and spheres of activity;

- increasing the interaction of government, business and the population of the regions and aggregating the interests of different social groups;

- ensuring economic and environmental security of the regional development under the conditions of regulation and ensuring socio-economic and organizational and legal foundations for the development of regional systems and the state as a whole.

The mobilization function helps to overcome obstacles to the development of regions under the conditions of effective interaction of all actors and rational use of resources, which in general makes it possible to obtain a synergistic effect for the development of regional economic systems.

One of the tasks of state management of the regional development is to improve the living standards of the population and to achieve sustainable development in the context of digital transformation, including by reducing the differentiation of regional development. This statement is the basis of the methodological approach proposed by the authors to assess the functions of public administration of the regional development in the context of digital trtansformation.

It should be noted that most often the impact of public administration of the regional development is determined through the calculation of integrated indices of the regional development. These indices provide an opportunity to determine the state, dynamics and trends of the socio-economic regional development. The positive thing in the calculation of integrated indices is that it is possible to obtain an objective assessment of the existing asymmetry of the development between regions. But integrated indices do not provide an opportunity to assess the impact of public administration on the regional development in the context of digital transformation through the functions of public administration. To determine the impact of the functions of public administration of the regional development, the model of differential equations is proposed for use.
Suppose that the model of public administration of the regional development in terms of digital transformation has common goals, which are reproduced in the presence of variables of the form $x(t)=\left(x_{1}, \ldots, x_{n}\right)$ and the functional $L(x, u)$, which must be minimized.

The mathematical parameter of the functional $\mathrm{L}$ minimization $(x, u)$ is the difference in the values of the integrated indices of social, reproductive and mobilization functions, as well as the complex integral index of the module of functions of the regions in time, type $f i(x, u, t)$.

The phase variables $x(t)$ in the differential equations of the model of the regional development management in the conditions of digital transformation are normalized estimation intdicators, which change with a certain time.

Functionality $L$ - is the minimization of the difference in the values of the integrated indices of the modules of social, reproductive and mobilization functions, as well as the complex integrated index of the module of the functions of economic development of the region.

The solution of the differential equations system of the model of determining the influence of public administration functions on the regional development in the conditions of digital transformation allows to obtain optimal values of regional management functionalities (social, reproductive and mobilization functions), which will reduce differentiation in values of integrated economic development indices.

When finding the integral indices of the modules of social, reproduction and mobilization functions and the complex integrated index of the module of the regional development management functional in the conditions of digital transformation, the linearization of the dependences of indicators and integrated indices in time dependence is used. It should be noted that the application of linearization simplifies the solution of the differential equations system to determine the impact of public administration of the regional development in the context of digital transformation.

The model for determining the impact of the functions of public administration of the regional development in terms of digital transformation, presented in the form of the following formula: 


$$
F(t, f)\left(\begin{array}{c}
f_{s}\left[s-\alpha\left(f_{s}+f_{v}+f_{m}-k\right)-\frac{\sin \left(f_{v}\right)}{f_{s}+b}\right] \\
f_{v}\left(v+\frac{f_{s}}{f_{s}+b}-\frac{f_{m}}{\sin \left(f_{v}\right)+b}\right) \\
f_{m}\left(m+\frac{f_{v}}{\sin \left(f_{v}\right)+b}\right)
\end{array}\right),
$$

Where: $f_{s}, f_{v}, f_{m}$ - differentiated functions by phase variables are constructed, namely social, reproductive and mobilization function;

$k-$ comprehensive integrated index of functionalities of state management of the regional development in the conditions of digital transformation;

$s, \quad v, m-$ coefficients of the differences of integrated indices values of the modules of social, reproductive and mobilization functions concerning values of indices of the development of the region with the highest rank.

$$
\begin{gathered}
s=\frac{\left(I_{s f c p_{j}}-I_{s f c p_{1}}\right) p}{l} \\
v=\frac{\left(I_{v f c p_{j}}-I_{v f c p_{1}}\right) p}{l}, \\
m=\frac{\left(I_{m f c p_{j}}-I_{m f c p_{1}}\right) p}{l}
\end{gathered}
$$

Where $p$ - the step of integrating the optimization function over time;

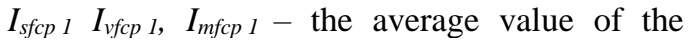
integrated index of the module of social, reproductive and mobilization functions of the region;

$I_{s f c p j}, I_{v f c p j}, I_{m f c p j}-$ the average value of the integral index of the module of social, reproductive and mobilization functions of the studied j-th region;

$l$ - the rank of the region by the value of integrated indices;

$b=k \cdot p$,

$\alpha$ - the step of integrating the values of the optimization function $\mathrm{L}$.

The approbation of the methodological approach proposed by the authors to determine the impact of the functions of public administration of the regional development in the context of digital transformation was carried out for the regions of Ukraine using the Mathcad-15 software. The basis for the calculations was a system of macroeconomic indicators, which were grouped in relation to the assessment of the module of social, reproductive and mobilization functions of the impact of public administration of the regional development in the context of digital transformation.

The values of the average integrated indices of the modules of social ( $\boldsymbol{I}_{\text {sf }}$ avg. $)$, reproductive ( $\boldsymbol{I}_{\boldsymbol{v} \text { f avg. }}$ ), and mobilization ( $\boldsymbol{I}_{\boldsymbol{m} \text { f avg. }}$ ) functions of determining the impact of public administration of the regional development in terms of digital transformation, as well as ranks according to their ratings are presented in Table 1.

Table 1.

\begin{tabular}{|c|c|c|c|c|c|c|}
\hline Regions & $I_{v f \text { avg. }}$ & $\begin{array}{l}\text { The rank of } \\
\text { the region by } \\
\text { value } I_{v f a v g .}\end{array}$ & $I_{\text {mf avg. }}$ & $\begin{array}{l}\text { The rank of } \\
\text { the region by } \\
\text { value } I_{r f a v g .}\end{array}$ & $I_{\text {sf avg. }}$ & $\begin{array}{l}\text { The rank of } \\
\text { the region by } \\
\text { value } I_{s f a v g .}\end{array}$ \\
\hline Vinnytsia & 4,06 & 5 & 4,29 & 5 & 4,30 & 4 \\
\hline Volyn & 1,56 & 22 & 1,56 & 22 & 0,75 & 22 \\
\hline Dnipropetrovsk & 4,68 & 4 & 8,20 & 3 & 4,52 & 3 \\
\hline Donetsk & 1,44 & 24 & 1,37 & 24 & 0,63 & 25 \\
\hline Zhytomyr & 1,96 & 17 & 2,34 & 15 & 2,51 & 15 \\
\hline Transcarpathian & 1,89 & 18 & 2,23 & 17 & 2,46 & 17 \\
\hline Zaporizhzhia & 2,57 & 10 & 3,23 & 9 & 3,31 & 9 \\
\hline Ivano-Frankivsk & 2,76 & 9 & 3,07 & 10 & 2,59 & 13 \\
\hline Kiev & 5,63 & 2 & 8,54 & 2 & 5,25 & 1 \\
\hline Kirovohrad & 1,99 & 16 & 2,32 & 16 & 2,48 & 16 \\
\hline
\end{tabular}

Ranks and average values of integrated indices of modules of social, reproductive and mobilization functions of state management of the regional development in the conditions of digital transformation in the regions of Ukraine for 2014-2020 


\begin{tabular}{|c|c|c|c|c|c|c|}
\hline Luhansk & 1,31 & 25 & 1,13 & 25 & 0,71 & 24 \\
\hline Lviv & 2,45 & 11 & 2,99 & 11 & 3,21 & 10 \\
\hline Mykolaiv & 2,08 & 14 & 2,50 & 14 & 2,63 & 12 \\
\hline Odessa & 2,31 & 12 & 2,78 & 12 & 3,11 & 11 \\
\hline Poltava & 2,80 & 8 & 3,27 & 8 & 3,47 & 8 \\
\hline Rivne & 2,15 & 13 & 2,62 & 13 & 2,58 & 14 \\
\hline Sumy & 1,85 & 19 & 2,16 & 18 & 2,40 & 18 \\
\hline Ternopil & 1,71 & 21 & 2,08 & 20 & 2,03 & 20 \\
\hline Kharkiv & 4,82 & 3 & 5,84 & 4 & 3,51 & 7 \\
\hline Kherson & 1,51 & 23 & 1,45 & 23 & 0,72 & 23 \\
\hline Khmelnytsky & 2,98 & 7 & 3,52 & 7 & 3,65 & 6 \\
\hline Cherkasy & 2,02 & 15 & 1,77 & 21 & 0,83 & 21 \\
\hline Chernivtsi & 3,32 & 6 & 3,71 & 6 & 3,90 & 5 \\
\hline Chernihiv & 1,76 & 20 & 2,13 & 19 & 2,33 & 19 \\
\hline Kyiv sity & 5,73 & 1 & 8,68 & 1 & 5,18 & 2 \\
\hline
\end{tabular}

Source: calculated by the authors.

Data presented in Table 1 show that despite the different values of the integral indices of the modules of social, reproductive and mobilization functions, their ranks in different integral indices have no significant variations. And such regions as Volyn, Kirovohrad, Poltava and Kherson regions have the same levels of ranks of integrated indices for all integrated modules of social, reproductive and mobilization functions. In Table 2, the value of the complex integrated index of the module of social, reproductive and mobilization functions of determining the impact of the functions of public administration of the regional development in the context of digital transformation is shown.

Table 2.

Comprehensive integrated index of the module of the regional development management functions in the conditions of digital transformation for 2014-2020

\begin{tabular}{|c|c|c|c|c|c|c|c|c|c|}
\hline \multirow[b]{2}{*}{ Regions } & \multicolumn{7}{|l|}{$I_{\text {freg }}$} & \multirow[b]{2}{*}{ Ifreg avg. } & \multirow{2}{*}{$\begin{array}{l}\text { Rank of the } \\
\text { region by the } \\
\text { average value } \\
\text { of the } \\
\text { complex } \\
\text { integrated } \\
\text { index }\end{array}$} \\
\hline & 2014 & 2015 & 2016 & 2017 & 2018 & 2019 & 2020 & & \\
\hline Vinnytsia & 8,64 & 8,64 & 7,47 & 8,10 & 8,28 & 8,64 & 9,72 & 8,50 & 5 \\
\hline Volyn & 2,88 & 3,38 & 2,93 & 3,51 & 3,53 & 3,55 & 3,60 & 3,34 & 20 \\
\hline Dnipropetrovsk & 11,07 & 11,97 & 11,34 & 10,89 & 12,33 & 11,07 & 9,72 & 11,20 & 3 \\
\hline Donetsk & 2,61 & 2,79 & 2,97 & 2,97 & 2,52 & 2,16 & 1,98 & 2,57 & 24 \\
\hline Zhytomyr & 4,59 & 4,69 & 4,95 & 5,18 & 4,59 & 4,64 & 4,73 & 4,76 & 16 \\
\hline Transcarpathian & 4,14 & 4,23 & 4,05 & 3,87 & 4,19 & 4,50 & 3,96 & 4,13 & 17 \\
\hline Zaporizhzhie & 6,35 & 6,30 & 6,26 & 6,35 & 6,39 & 6,12 & 6,26 & 6,29 & 9 \\
\hline Ivano-Frankivsk & 5,94 & 5,40 & 5,49 & 5,49 & 5,67 & 6,39 & 6,48 & 5,84 & 12 \\
\hline Kiev & 14,04 & 13,77 & 13,59 & 13,23 & 13,05 & 13,59 & 15,03 & 13,76 & 1 \\
\hline Kirovohrad & 4,68 & 4,64 & 4,91 & 5,18 & 5,72 & 5,85 & 5,40 & 5,19 & 15 \\
\hline Luhansk & 2,16 & 2,70 & 2,88 & 2,70 & 2,07 & 1,80 & 1,71 & 2,29 & 25 \\
\hline Lviv & 6,30 & 6,17 & 6,03 & 5,99 & 6,21 & 6,35 & 6,12 & 6,17 & 10 \\
\hline Mykolaiv & 5,18 & 5,22 & 6,30 & 5,31 & 5,58 & 6,03 & 5,81 & 5,63 & 14 \\
\hline Odessa & 6,03 & 5,58 & 5,63 & 6,30 & 6,39 & 6,21 & 6,03 & 6,02 & 11 \\
\hline Poltava & 6,30 & 6,39 & 6,35 & 6,44 & 6,48 & 6,44 & 6,39 & 6,40 & 8 \\
\hline Rivne & 5,13 & 5,49 & 5,67 & 5,81 & 5,85 & 5,94 & 5,63 & 5,64 & 13 \\
\hline Sumy & 3,60 & 3,65 & 3,51 & 3,69 & 3,74 & 3,60 & 3,69 & 3,64 & 19 \\
\hline Ternopil & 3,65 & 3,51 & 3,24 & 2,84 & 2,79 & 2,70 & 2,61 & 3,05 & 22 \\
\hline Kharkiv & 9,72 & 9,81 & 9,90 & 9,90 & 9,90 & 9,99 & 10,17 & 9,91 & 4 \\
\hline Kherson & 3,15 & 2,97 & 2,88 & 2,79 & 2,57 & 2,70 & 2,52 & 2,80 & 23 \\
\hline Khmelnytsky & 7,20 & 7,07 & 6,84 & 6,93 & 7,16 & 6,84 & 6,75 & 6,97 & 7 \\
\hline
\end{tabular}




\begin{tabular}{|c|c|c|c|c|c|c|c|c|c|}
\hline Cherkasy & 3,33 & 3,33 & 3,60 & 3,06 & 2,88 & 3,06 & 3,33 & 3,23 & 21 \\
\hline Chernivtsi & 7,11 & 7,16 & 7,20 & 6,84 & 7,29 & 7,38 & 7,47 & 7,21 & 6 \\
\hline Chernihiv & 4,16 & 4,21 & 3,96 & 3,83 & 4,10 & 4,32 & 3,78 & 4,05 & 18 \\
\hline Kyiv sity & 11,34 & 12,15 & 12,60 & 13,14 & 12,60 & 13,14 & 14,04 & 12,69 & 2 \\
\hline $\begin{array}{l}\text { The arithmetic mean } \\
\text { value of a complex } \\
\text { integral index (Ifreg avg.) }\end{array}$ & 5,97 & 6,05 & 6,02 & 6,01 & 6,08 & 6,12 & 6,12 & 6,05 & - \\
\hline
\end{tabular}

Source: calculated by the authors.

Presented in Table 2 values of the complex integrated index of the module of social, reproductive and mobilization functions of determining the impact of public administration functions of the regional development in the conditions of digital transformation demonstrate that during the studied period there is no region of Ukraine in which positive or negative changes constantly occur. The dynamics of the arithmetic mean value of a complex integral index also has no general tendency to change. The highest values were observed in 2019-2020 (Ifreg avg. $=6.12), \quad$ the lowest in 2014 $\left(\boldsymbol{I}_{\text {freg avg }}=5.97\right)$, but in 2016-2017 (respectively $\left.I_{\text {freg avg. }}=6,02\right),\left(I_{\text {freg avg. }}=6.01\right)$, the values of the complex integrated index were smaller than the value of the complex index in 2015 $\left(I_{\text {freg avg. }}=6.05\right)$.

The indicators of the complex integrated index clearly illustrate the significant asymmetry in the values between the regions. Thus, the difference between the leader Kiev region $\left(I_{v f \text { avg. }}=13.76\right)$ and Luhansk region, which occupies the lowest step in terms of the value of the average complex integrated index $\left(I_{v f \text { avg. }}=2.29\right)$ is 6 times.
The presented values of integrated indices of modules of social, reproduction and mobilization functions, as well as the complex integrated index of the module of the regional development management functions in digital transformation are the basis for assessing the impact of state management of the regional development in digital transformation on economic development of regions using differential equations.

The cyclical nature of the economic development of the region in terms of digital transformation is visualized in Fig. 1. Different weights of economic development efforts on the part of public administration functions of the regional development in the conditions of digital transformation are characterized by dynamic changes of the amplitude of fluctuations of integral indices of modules of functionals of social, reproductive and mobilization functions presented in time $\left(U^{\langle 0}\right)$.

In Fig. 1 on the abscissa axis is the time period $(r=14)$, in our case the years from 2021 to 2034 .
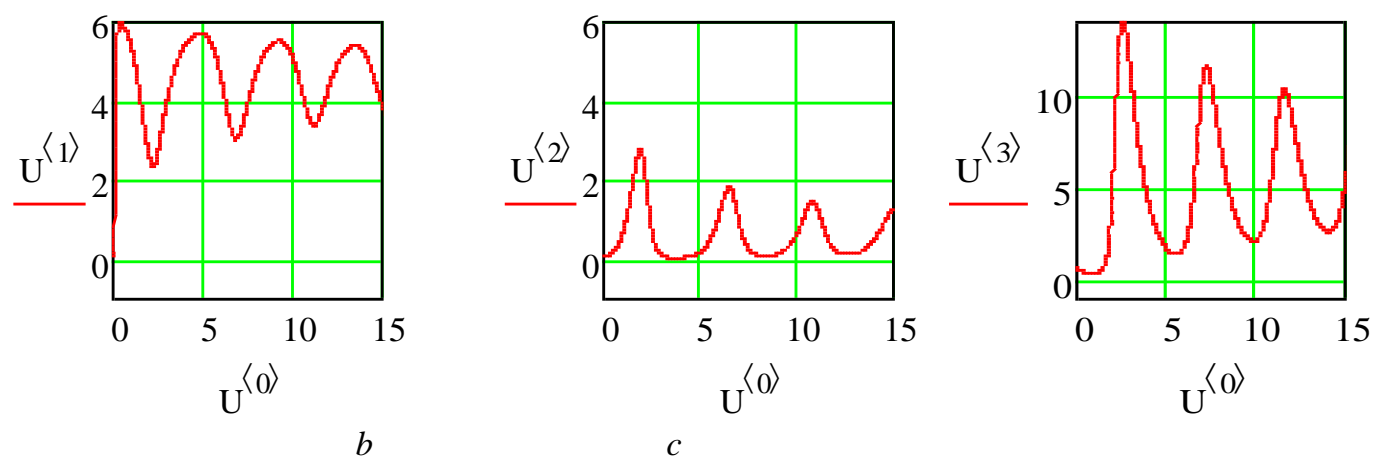

Figure 1. Visualization of dynamic changes in the amplitude of fluctuations of integrated indices of modules of functionalities of state management of the regional development in terms of digital transformation represented by time $\mathrm{U}^{\langle 0\rangle}$, on the example of Chernihiv region, where: a - oscillations of reproduction $\left(U^{\langle 1)}\right)$; b - mobilization $\left(U^{\langle 2\rangle}\right)$; in - social $\left(U^{(3)}\right)$ functions of state management of the regional development in the conditions of digital transformation. Source: built by the authors.

In this case, such visualization illustrates not only the periodicity, but also the gradual reduction of the impact of the functions of public administration of the regional development in terms of digital transformation on the economic development of the region. But such dynamic changes do not take into account the impact of changes in the modules of the functions of public 


\section{AMAZONIA
Trvestiga}

administration of the regional development in the context of digital transformation during this period, which will change their dynamics. That is, greater activity of the functions of state management of the regional development in the context of digital transformation has a greater impact on the economic development of the region.

\section{Conclusions}

Social, reproductive and mobilizing functions of public administration of the regional development, which were identified in accordance with a systematic approach focused on performing certain tasks within relevant function in terms of digital transformation, as well as aimed at improving living standards of regions by modernizing the economy of regional economic systems, are objective in nature, relatively independent, and are subject to the goals of the regional and social development in general.

The scientific novelty of this study is the development of a methodological approach based on the model of the differential equations system to determine social, reproductive and mobilizing functions of public administration of the regional development in the context of digital transformation.

The use of the differential equations system to determine the impact of public administration of the regional development in the context of digital transformation will contribute to:

- overcoming the decline in the development of regional economic systems;

- increasing economic growth in the conditions of digital transformation of underdeveloped and depressed regions;

- ensuring by the state guaranteed by the population standards of quality of life and development of human potential in the conditions of digital transformation;

- increasing effective employment in the regions;

- more efficient and careful use of regional development resources;

- development of intellectual and innovative potential of regions and increase of innovative activity;

- increasing the competitiveness and investment attractiveness of territories, etc.
Further research in the direction of improving the efficiency of public administration of the regional development requires determining the impact of digital transformation on the development of regions in modern conditions.

\section{Bibliographic references}

Arefieva, O., Tulchynska, S., Popelo, O., Arefiev, S., \& Tkachenko, T. (2021). The Economic Security System in the Conditions of the Powers Transformation. IJCSNS International Journal of Computer Science and Network Security, 21(7), 35-42. https://doi.org/10.22937/IJCSNS.2021.21.7.4

Becerra, L., Carenzo, S., \& Juarez, P. (2020). When circular economy meets inclusive development. Insights from urban recycling and rural water access in Argentina. Sustainability, 12(23), $9809 . \quad$ DOI: https://doi.org/10.3390/su12239809

Bouckaert, G. (2019). Dissemination of scientific knowledge on reforming public administration: Some changing mechanisms. Croatian and Comparative Public Administration, 19(1), 9-22. DOI: https://doi.org/10.31297/hkju.19.1.1.

Castellanos, J. M. B. (2019). La responsabilidad social en las administraciones públicas, con especial referencia a la Comunitat Valenciana. Revista General de Derecho Administrativo, 52. De Leon, C.A.G. (2019). The role of public administration in promoting socio-economic development. In Social Development and Societies in Transition (pp. 107-120). London: Imprint Routledge.

Efremov, A. (2020). In reference to creating a mechanism for detecting systemic legal limitations of public administration digitalization. Public Administration Issues, 4, 59-83.

Halkos, G., Moll de Alba J., \& Todorov, V. (2021). Economies' inclusive and green industrial performance: An evidence based proposed index. Journal of Cleaner Production, 279, $123516 . \quad$ DOI: https://doi.org/10.1016/j.jclepro.2020.123516. Houston, D., Varna, G., \& Docherty, I. (2021). The political economy of and practical policies for inclusive growth- A case study of Scotland. Cambridge Journal of Regions, Economy and Society, 14(1), pp. 197-2151. DOI: https://doi.org/10.1093/cjres/rsaa039.

Khanin, S., Tulchynska, S., Popelo, O., Derhaliuk, M., \& Ishchejkin, T. (2021). Systematization of functional features of intellectual and innovative determinants of the intensification of the regional economic development. Laplage em Revista (International), $\quad 7(2), \quad$ 710-720. 
https://doi.org/10.24115/S2446-

62202021721118p.710-720.

Kiseleva, O., Lebedev, A., Pinkovetskaia, I., Rojas-Bahamón, M., \& Arbeláez Campillo, D. (2019). Specialization and concentration of small and medium enterprises employees: Russian data. Amazonia Investiga, 8(20), 6-15. Retrieved from

https://amazoniainvestiga.info/index.php/amazo nia/article/view/59

Krasniqi, I. (2019). Strategic management for regional economic development and business sustainability: Countries in transition. International Journal of Economics and Business Administration, 7(4), 47-67.

Kraynyuk, L., Uhodnikova, O., Vlashchenk, N., Sokolenko, A., \& Viatkin, K. (2020). The mechanism of public administration of the travel industry development: Prospects for the ecotourism development. In XIII International Scientific and Practical Conference "State and Prospects for the Development of Agribusiness INTERAGROMASH 2020", 175, 10016. DOI: https://doi.org/10.1051/e3sconf/202017510016. Ljungholm, D. P. (2017). Global policy mechanisms, intergovernmental power politics, and democratic decision-making modes of transnational public administration. Geopolitics, History, and International Relations, 9(2), 199-205.

Mukhametzhan, S., Junusbekova, G., \& Daueshov, M. (2020). The management of Urban development for the regional economic growth: The example of Kazakhstan. Economy of Region, 16(4), 1285-1301. DOI: https://doi.org/10.17059/ekon.reg.2020-4-19.

Petit, J., \& Brunet, S. (2017). Does anticipation matter for public administration? The case of the Walloon Region (Belgium). Foresight, 19(3), 280-290. DOI: https://doi.org/10.1108/FS-102016-0049.

Salbaroli, E., \& Mazzini, G. (2018). OCP Deployment in a Public Administration Data Center: The Emilia-Romagna Region Use Case.
In IEEE International Black Sea Conference on Communications and Networking (BlackSeaCom). 10.1109/BlackSeaCom.2018.8433637.

Samiilenko, H., Popelo, O., Khudolei, V., Mashnenkov, K., \& Derkachenko, Yu. (2021). Transformational processes of clustering in digital economy. Laplage em Revista (International), 7(Extra C), 691-702. https://doi.org/10.24115/S2446-

622020217Extra-C1106p.691-702

Samoilovych, A., Garafonova, O., Popelo, O., Marhasova, V., \& Lazarenko, Yu. (2021). World experience and ukrainian realities of digital transformation of regions in the context of the information economy development. Financial and credit activity: problems of theory and practice, (3(38)), 316-325. https://doi.org/10.18371/fcaptp.v3i38.237462 .

Skica, T., \& Dvouletý, O. (2018). Quantification of the size of local public administration: Empirical study of Polish regions. European Spatial Research and Policy, 25(1), 75-92. DOI: https://doi.org/10.18778/1231-1952.25.1.05.

Wu, D. (2018). Computer model deduction based on function mechanism of government microblog's participation in public administration. Journal of Advanced Oxidation Technologies, 21(2), 201811577.

Xu, Y., \& Li, A. (2019). Regional economic development coordination management system based on fuzzy hierarchical statistical model. Neural Computing and Applications, 31(12), 8305-8315.

DOI: https://doi.org/10.1007/s00521-018-3953-8.

Yin, X. (2018). Construction of management system for coordination degree of regional economic development based on the fusion of spatial econometric model. In 10th International Conference on Measuring Technology and Mechatronics Automation (ICMTMA), 17703620 . DOI: 